\title{
First Records of the Arctic Moth Gynaephora groenlandica (Wocke) South of the Arctic Circle: A New Alpine Subspecies
}

\author{
ISABEL C. BARRIO, ${ }^{1,2}$ B. CHRISTIAN SCHMIDT, ${ }^{3}$ SYDNEY CANNINGS ${ }^{4}$ and DAVID S. HIK ${ }^{1}$
}

\author{
(Received 10 December 2012; accepted in revised form 11 March 2013)
}

\begin{abstract}
Two adjacent populations of the Arctic moth Gynaephora groenlandica, a High Arctic endemic species, were found in southwest Yukon, ca. $900 \mathrm{~km}$ south of the species' described distribution. Species identification was based on larval morphology for one population and on larvae rearing and DNA barcoding for the other. All three approaches clearly separated G. groenlandica from the closely related and frequently sympatric G. rossii. These records represent the first reports of G. groenlandica in alpine environments, and we recognize these populations as a distinct subspecies, G. g. beringiana, on the basis of differences in habitat, geography, wing phenotype, and DNA barcode. Given the limited dispersal ability of G. groenlandica, these records may represent isolated relict populations. Disjunct populations and new records of other species recently described for the southwest Yukon suggest 1) that this region is understudied and a potential refugium for species characteristic of different biogeographic influences and 2) that this region may be changing considerably in response to recent rapid environmental change, which has influenced species distribution, abundance, and phenology. Our findings, however, might result from a relatively poor description of the arthropod fauna of remote locations; these discoveries should therefore instigate further survey efforts.
\end{abstract}

Key words: glacial refugia, Kluane, Lepidoptera, Lymantriinae, Ogilvie, range extension, relict populations

RÉSUMÉ. Deux populations adjacentes du papillon de nuit de l'Arctique Gynaephora groenlandica, espèce endémique de l'Extrême-Arctique, ont été trouvées dans le sud-ouest du Yukon, à environ $900 \mathrm{~km}$ au sud de la répartition décrite pour cette espèce. L'espèce a été identifiée à l'aide de la morphologie de la larve d'une population, et à l'aide de la croissance de la larve et de la codification à barres génétique de l'autre population. Les trois méthodes ont permis de distinguer clairement G. groenlandica de G. rossii, espèce étroitement liée et souvent sympatrique. Il s'agit des premières observations de G. groenlandica en milieu alpin, et nous reconnaissons ces populations comme étant une sous-espèce distincte, G. g. beringiana, en raison des différences sur le plan de l'habitat, de la géographie, du phénotype de l'aile et de la codification à barres génétique. Puisque la capacité de dispersion de G. groenlandica est restreinte, ces observations pourraient représenter des populations reliques isolées. Des populations isolées et de nouvelles observations d'autres espèces décrites récemment dans le sud-ouest du Yukon suggèrent 1) que cette région n'est pas suffisamment étudiée et qu'elle pourrait être un refuge pour des espèces caractéristiques d'influences biogéographiques différentes, et 2) qu'il est possible que cette région soit en train de changer considérablement en raison de l'altération rapide et récente de l'environnement, ce qui exerce une influence sur la répartition, l'abondance et la phénologie des espèces. Toutefois, nos constatations pourraient découler d'une description relativement mauvaise de la faune arthropode des régions éloignées et par conséquent, ces découvertes devraient inciter la réalisation d'études supplémentaires.

Mots clés: refuge glaciaire, Kluane, Lepidoptera, Lymantriinae, Ogilvie, étendue du parcours, populations reliques

Traduit pour la revue Arctic par Nicole Giguère.

\section{GYNAEPHORA SPECIES IN NORTH AMERICA}

Two species of the genus Gynaephora Hübner (Lepidoptera: Erebidae, Lymantriinae; Lafontaine and Schmidt, 2010) are represented in North America: G. rossii (Curtis, 1835) and G. groenlandica (Wocke, 1874). The two species co-occur at many sites in the Canadian Arctic, but their geographic distributions are not totally overlapping (Fig. 1). Gynaephora rossii has a Holarctic Arctic-alpine distribution; in North America, it occurs in the Arctic (except Greenland) and subarctic regions south to the northern Rocky Mountains of British Columbia, with isolated populations in the

\footnotetext{
${ }^{1}$ Department of Biological Sciences, University of Alberta, Edmonton, Alberta T6G 2E9, Canada

${ }^{2}$ Instituto de Investigación en Recursos Cinegéticos (CSIC-UCLM-JCCM), Ronda de Toledo s/n, 13071 Ciudad Real, Spain; corresponding author: icbarrio@gmail.com

${ }^{3}$ Canadian Food Inspection Agency, Ottawa Plant Laboratory (Central Experimental Farm) - Entomology, 960 Carling Avenue, Ottawa, Ontario K1A 0C6, Canada

${ }^{4}$ Environment Canada, Canadian Wildlife Service, Whitehorse, Yukon Y1A 3C9, Canada

(C) The Arctic Institute of North America
} 


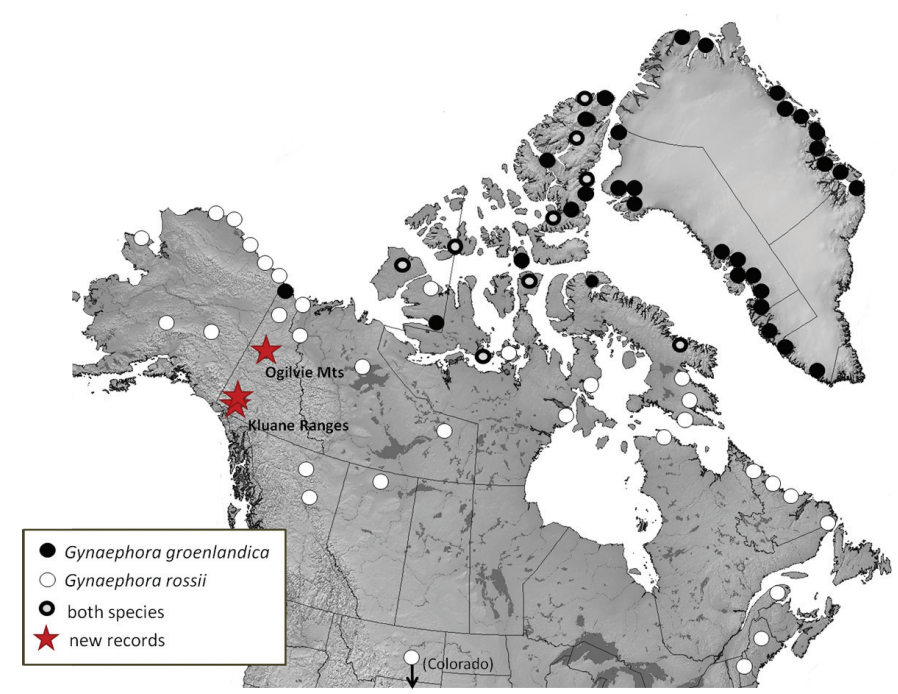

FIG. 1. Distribution map of G. groenlandica and G. rossii in North America and Greenland, based on Wolff (1964), Ferguson (1978), Mølgaard and Morewood (1996), Pohl et al. (2010), and specimens examined in this study. Yukon sites for G. groenlandica beringiana are indicated with a red star.

northern Appalachians and the Colorado Rocky Mountains (Fig. 1). A subarctic population was recently discovered in northern Alberta (Pohl et al., 2010). In the Palaearctic, $G$. rossii occurs in Siberia west to the Ural Mountains (Witt and Ronkay, 2011) and in the alpine regions of Japan (Ferguson, 1978). Gynaephora groenlandica is endemic to the North American High Arctic (Downes, 1964), occurring in Greenland and the Canadian Arctic Archipelago (Wolff, 1964). Only one prior record is known from the mainland of North America, in the northern Yukon (Ferguson, 1978; Lafontaine and Wood, 1997).

The two species, though closely related, are reproductively isolated, so no hybrids occur (Morewood, 1998). Immature stages are the most conspicuous life stage (Ferguson, 1978), but their identification has created some confusion that persists in the literature (Morewood and Lange, 1997). Larvae of both species can vary in colour (Schaefer and Castrovillo, 1979; Morewood and Lange, 1997), but the later instars can be readily distinguished by the form of the hairs (spinulose in G. groenlandica and plumose in $G$. rossii) and the colour patterns of their dorsal hair tufts (Morewood and Lange, 1997). In general, larvae of G. groenlandica are larger and have longer, more uneven hairs than those of G. rossii (Morewood and Lange, 1997). Rarely, larvae of G. rossii may lack the characteristic grey plumose hairs (Morewood, 1998), but the pattern of dorsal hair tufts is different in such cases, with no black tuft at the tail end (Mølgaard and Morewood, 1996). In fact, this hair tuft on the eighth abdominal segment, described as a "rudimentary hair pencil" (Ferguson, 1978:19), is characteristic of G. groenlandica. Cocoons of the two species are spun on exposed sites, such as rocks, and are distinctive; those of G. groenlandica are larger and have two layers, in contrast to the single-layered cocoons of G. rossii (Morewood and Lange, 1997). Larval hairs are incorporated into the
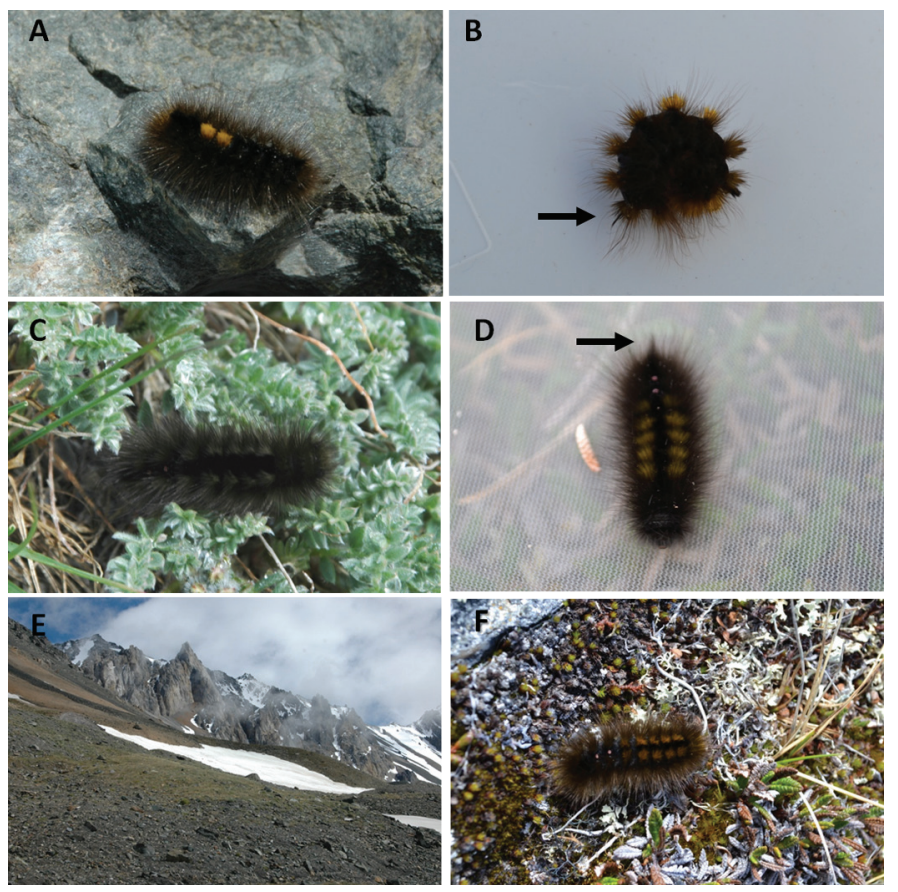

FIG. 2. Larvae of Gynaephora groenlandica beringiana found in SW Yukon, in Silver Creek in summer 2010 (A, C) and in the Ruby Range in summer 2012 (B, D, F), and typical alpine habitat in Silver Creek (E). Early (A, B) and middle instars (C, D, F) of G. groenlandica show long hairs (and the lack of grey plumose hairs). Early instars show the distinctive pattern of two tufts of black and two tufts of yellow on the back, as well as a black tuft at the tail end that is preserved in later instars (indicated by arrows in B and D), typical of the species. Many larvae in Silver Creek were found on Oxytropis arctica var. murrayii, a disjunct population of an otherwise Arctic endemic plant (C: freshly moulted larva, as shown by the colour pattern). In the Ruby Range, most larvae occurred in the dry tundra-boulder field ecotone (F).

cocoon, and the presence of spinulose versus plumose hairs can help distinguish the two species (Mølgaard and Morewood, 1996). Wing patterns of adults also differ: G. rossii has more marked patterns, and it has a broad dark band along the margin of the hind wings, which is lacking in $G$. groenlandica (Ferguson, 1978; Mølgaard and Morewood, 1996). However, adults are more difficult to find in the field (Wolff, 1964; Lafontaine and Wood, 1997). The adult lifespan is very brief, with emergence and reproduction occurring within a $24 \mathrm{~h}$ period (Kukal and Kevan, 1987), and as in a number of other lymantriine moths, females do not fly. Males fly very actively during the day and are described as flying "high, fast and erratically" (Ferguson, 1978:19).

\section{YUKON OCCURRENCES}

Except for a record from the Arctic Coast (Lafontaine and Wood, 1997), G. groenlandica was not previously known to occur in the Yukon. On 18 June 2010, we found and collected $30 \mathrm{G}$. groenlandica larvae from an alpine site at $1785 \mathrm{~m}$ elevation, at the headwaters of Silver Creek in the Kluane Ranges, SW Yukon $\left(60^{\circ} 54^{\prime} \mathrm{N}, 138^{\circ} 21^{\prime} \mathrm{W}\right.$; Fig. 2E). Two years later, on 15 July 2012, we found several G. groenlandica larvae in an alpine valley of the Ruby 

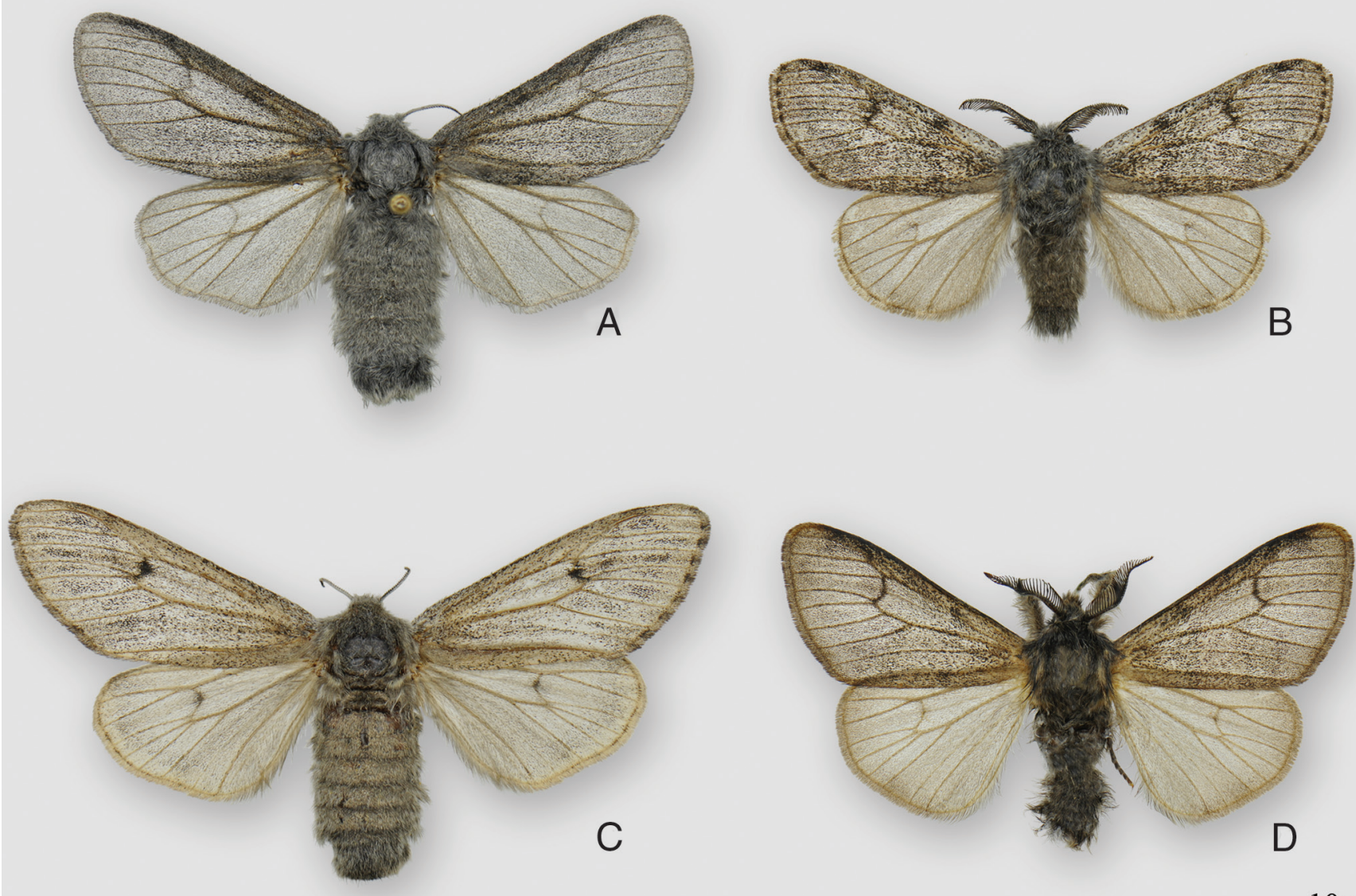

$10 \mathrm{~mm}$

FIG. 3. Adults of Gynaephora groenlandica. G. g. beringiana female holotype, Kluane Ranges, Yukon (A) and male paratype, Ogilvie Mountains, Yukon (B). G. g. groenlandica female, Alexandra Fiord, Ellesmere Island, Nunavut (C) and male, Hazen Camp, Ellesmere Island, Nunavut (D).

Range, SW Yukon $\left(61^{\circ} 12^{\prime} \mathrm{N}, 138^{\circ} 16^{\prime} \mathrm{W}\right.$; Fig. 2A-D, F). The two sites are ca. $30 \mathrm{~km}$ apart. Examination of specimens in the Canadian National Collection of Insects, Arachnids, and Nematodes (CNC) of Agriculture and Agri-Food Canada also revealed a specimen from the Ogilvie Mountains $400 \mathrm{~km}$ to the north. No previous records for this species are known south of the Arctic Circle, and the SW Yukon records are ca. $900 \mathrm{~km}$ south of the southern limit of its described distribution range (Ferguson, 1978).

We attempted to rear the larvae collected from Silver Creek in the lab, but only one female completed development to the adult stage (Fig. 3A). We compared this population to other Gynaephora specimens in the CNC and sequenced the $658 \mathrm{bp}$ "barcode" region of the first subunit of the cytochrome oxidase (coxl) gene (Ratnasingham and Hebert, 2007). Tissue from specimens (1-2 legs) was submitted to the Biodiversity Institute of Ontario, University of Guelph, where samples were processed through the "Barcode of Life Data Systems" (BOLD; Ratnasingham and Hebert, 2007). Haplotypes of all barcodes were compared with phylograms constructed using the neighbour-joining method as implemented on the BOLD website. Identification of specimens from the Ruby Range was based on larval morphology only. Gynaephora rossii was also present at this site, but larvae of the two species could be readily distinguished using the diagnosis in Morewood and Lange (1997). Estimated larval densities from transects conducted in the dry tundra-boulder field ecotone in the Ruby Range were 0.02 larvae $/ \mathrm{m}^{2}$ ( $\mathrm{SD}=0.04$; Barrio et al., 2013), a density consistent with those of High Arctic populations (Kukal and Kevan, 1987).

Comparison of the reared female specimen and a male specimen from the Ogilvie Mountains to those from High Arctic populations shows the alpine G. groenlandica to differ noticeably in wing phenotype. Also, DNA barcode haplotypes of the two Yukon specimens differed from four Arctic specimens (Table 1) by $0.46 \%-0.47 \%$ (Kimura 2 -parameter distance model). Variation within the Nunavut specimens ranged from $0.0 \%$ to $0.31 \%$. Further comparison of DNA barcodes of G. groenlandica through the BOLD database shows that Arctic and Greenland populations exhibit shared or similar haplotypes, which again differ from the Yukon population. Given the differences in habitat, geography, wing phenotype, and DNA barcode, we recognize these alpine populations as a distinct subspecies: Gynaephora groenlandica beringiana Schmidt and Cannings (Fig. 3A, B). 
TABLE 1. Specimens of Gynaephora groenlandica used for DNA barcode haplotype comparison.

\begin{tabular}{|c|c|c|c|c|c|c|}
\hline Taxon & DNA voucher \# & Locality & Latitude & Longitude & Date & Collector \\
\hline Gynaephora g. beringiana & acrorev gga1 & $\begin{array}{l}\text { Yukon, Kluane Ranges, } \\
\text { Silver Creek headwaters }\end{array}$ & 60.898 & -138.346 & 18 June 2010 & S. Cannings \\
\hline Gynaephora g. beringiana & acrorev gga2 & $\begin{array}{l}\text { Yukon, Kluane Ranges, } \\
\text { Silver Creek headwaters }\end{array}$ & 60.898 & -138.346 & 18 June 2010 & S. Cannings \\
\hline Gynaephora g. groenlandica & CNCLEP00028423 & Nunavut, Bylot Island & 73.157 & -79.964 & 25 July 2006 & L. Jolicoeur \\
\hline Gynaephora g. groenlandica & CNCLEP00028424 & Nunavut, Bylot Island & 73.157 & -79.964 & 31 July 2006 & L. Jolicoeur \\
\hline Gynaephora g. groenlandica & CNCLEP00028425 & Nunavut, Bylot Island & 73.157 & -79.964 & 31 August 2006 & L. Jolicoeur \\
\hline Gynaephora g. groenlandica & LEP038069 & $\begin{array}{l}\text { Nunavut, Ellesmere Island, } \\
\text { Alexandra Fiord }\end{array}$ & 78.883 & -75.917 & 18 June 1995 & W.D. Morewood \\
\hline
\end{tabular}

\section{GYNAEPHORA GROENLANDICA BERINGIANA}

\section{Description}

The new subspecies can be described as follows: Vestiture of head, thorax, abdomen and legs an even, lead grey; male antennae bipectinate, longest rami about 10 times as long as length of segments; female antennae short (1/4 length of forewing) and weakly biserrate; eyes reduced and ellipsoidal, as in most other diurnal Arctic-alpine noctuoid moths; eye reduction more pronounced in female; forewing length $19.5 \mathrm{~mm}$ in female, $17.5 \mathrm{~mm}$ in male; wing markings completely lacking in female, forewing lead grey with sparse fine black scaling faintly visible; fringe concolorous; hindwing slightly paler and more translucent; male forewing hoary grey and peppered with black scaling, faint patterning consisting of a black, diffuse discal spot and remnants of an antemedial and a postmedial fascia, each represented by indistinct black bars at the costal margin; hindwing slightly paler and more translucent, lacking scattered black scales and pattern.

\section{Diagnosis}

This subspecies is distinguished from G. g. groenlandica (Fig. 3C, D) by the colour of the adults, geographic distribution, and DNA barcodes. The wings and body vestiture of G. g. beringiana are a lead-grey ground colour, compared to the decidedly tan-brown cast of G. g. groenlandica. Subspecies beringiana occurs in high alpine habitats of the Yukon, whereas groenlandica occurs from the Arctic coastal plain north to Ellesmere Island and Greenland. Genitalic structure was not examined, but is presumably like the very simple structure of the nominate subspecies described and illustrated in Ferguson (1978). The DNA barcode haplotype is distinct from those of other G. groenlandica sampled to date and is available on the GenBank database (accession numbers JN280825 and JN280826). Ferguson (1978: Plate 1, Fig. 29) illustrated and discussed an unusually pale-tan specimen from Firth River in the British Mountains on the Arctic Coast; examination of this specimen $(\mathrm{CNC})$ suggests that the unusual colouration is the result of bleaching through prolonged exposure to sunlight, or possibly exposure to an unknown chemical. A second, reared female specimen from the British Mountains agrees well with typical Arctic populations of G. groenlandica, and we therefore assign these northern Yukon specimens to the nominate subspecies.

\section{Type Material}

The following specimens were used to describe the new subspecies: Holotype + (Fig. 3A). CAN: Yukon Territory, Kluane Ranges, headwaters of Silver Creek, 1785 m, rocky tundra, ex larva coll. 18.Jun.2010, leg. S. Cannings. Voucher \# CNCLEP00094172; DNA voucher \# "acrorev ggal"; GenBank accession \# JN280825; (CNC). Paratype $\widehat{~}$ (Fig. 3B), Yukon, Dempster Highway km 155 [Windy Pass, Ogilvie Mountains], 16-18.Jul.1981, leg. D. Lafontaine \& G. \& M. Wood; (CNC).

\section{Etymology}

The name beringiana reflects the fact that these populations likely persisted in alpine habitats of the Beringian refugium during the last glacial maximum.

\section{DISCUSSION}

These southern, alpine populations of G. groenlandica beringiana are especially interesting from an ecological point of view. G. groenlandica is well adapted to cold Arctic environments (Danks, 2004) and it has never before been described in an alpine environment. Its life cycle, with an extraordinarily extended developmental period (Morewood and Ring, 1998), is a consequence of low Arctic temperatures, the nutritional quality of its preferred host plants, and parasitism (Kukal and Kevan, 1987; Kukal and Dawson, 1989; Kukal, 1995). Low temperatures constrain larval metabolism and feeding activities, but biotic factors confine larval activity to a brief period (ca. three weeks) immediately following snowmelt, after which the larvae spin hibernacula and become dormant until the following spring (Kukal and Dawson, 1989; Morewood and Ring, 1998). However, alpine populations are exposed to conditions different from those in the High Arctic, such as different seasonal and daily patterns of temperature and photoperiod (Danks, 1999), and their life histories may differ. Such a difference has been reported for G. rossii: alpine 
populations have a shorter development cycle (estimated as $2-3$ years vs 10 years in Arctic populations), females are more mobile than their flightless Arctic counterparts, and larvae feed on a broader spectrum of plants (Schaefer and Castrovillo, 1979). For example, it is notable that the larvae we found in 2012 were active in mid-July. In the High Arctic, G. groenlandica larvae were reported to be active only earlier in the season, ceasing their feeding activity and starting to spin their hibernacula by the end of June, to avoid the peak of activity of adult parasitoids (Kukal and Kevan, 1987). However, the summer of 2012 was particularly cold (on average $2^{\circ} \mathrm{C}$ below the normal; D.S. Hik, unpubl. data), with snow cover almost until the end of June. To what extent this later activity period represents a local adaptation to alpine environments or a phenotypic response to an exceptionally late summer remains to be investigated.

It is interesting to note that, at the Silver Creek site, one of the dominant plants was Oxytropis arctica var. murrayii (Jurtsev) S.L. Welsh (Fabaceae), a southern disjunct form of an otherwise Arctic endemic species (Cody et al., 2005). Many of the caterpillars observed were climbing on these plants, and perhaps feeding on them (Fig. 2C). Another plant species, Puccinellia vahliana (Liebm.) Scrib. and Merr. (Poaceae), shows a disjunct distribution similar to that of $O$. arctica, and it is found on Mt. Decoeli, a nearby peak in the Kluane Ranges area (B. Bennett, pers. comm. 2012). Pleistocene glaciations have shaped the distribution of many plants and animals in the Yukon (Lausi and Nimis, 1985; Danks et al., 1997; Harris, 2004). There have been several reports of range extensions and new species from the southwest Yukon over the past decade (Lafontaine and Troubridge, 1999; Cody et al., 2004, 2005), suggesting (1) that this region is understudied and a potential refugium for species characteristic of Beringian, Cordilleran, Arctic, Boreal, and Maritime biogeographic influences (Lausi and Nimis, 1985); and (2) that this region may be experiencing considerable change in response to recent and rapid environmental change influencing species distribution, abundance, and phenology. These populations of G. groenlandica may also represent isolated relict populations, but further evidence is needed. Gynaephora groenlandica may be particularly prone to regional isolation and relictualism because females are flightless, and dispersal between alpine habitats of separate mountain ranges is therefore expected to be limited. In any case, these records of G. groenlandica are the first reports of this species in alpine environments and extend its known distribution range considerably to the south. Our findings might result from the relatively poor description of arthropod fauna of remote locations, and these discoveries should therefore instigate further survey efforts.

\section{ACKNOWLEDGEMENTS}

Special thanks are due to Dean Morewood, who started this project by identifying the caterpillars from the Ruby Range; he also provided detailed comments on earlier versions of the manuscript. We are grateful to Don Lafontaine and two anonymous reviewers, who improved earlier versions of this manuscript. We would also like to thank Shannon Stotyn and Lee Mennell for their assistance in collecting the caterpillars at Silver Creek and Gary Anweiler for his help in rearing the caterpillars. Jocelyn Gill (CNC, Ottawa, Canada) kindly provided assistance with photography. Molecular analyses were carried out at the Barcode of Life Project, University of Guelph, Ontario, Canada, through grants from the Natural Sciences and Engineering Research Council of Canada and Genome Canada. Funding for the fieldwork was provided by Environment Canada in 2010 and the Natural Sciences and Engineering Research Council of Canada in 2012. I.C. Barrio was supported by a postdoctoral fellowship provided by the Consejería de Educación, Ciencia y Cultura (Junta de Comunidades de Castilla-La Mancha [Council for Education, Science and Culture of the Regional Government of Castille and La Mancha, Spain]) and the European Social Fund.

\section{REFERENCES}

Barrio, I.C., Hik, D.S., Peck, K., and Bueno, C.G. 2013. After the frass: Foraging pikas select patches previously grazed by caterpillars. Biology Letters 9(3), 20130090.

Cody, W.J., Kennedy, C.E., Bennett, B., and Caswell, P. 2004. New records of vascular plants in the Yukon Territory VI. Canadian Field-Naturalist 118(4):558-578.

Cody, W.J., Bennett, B.A., and Caswell, P. 2005. New records of vascular plants in the Yukon Territory VII. Canadian Field Naturalist 119(3):417-436.

Danks, H.V. 1999. Life cycles in polar arthropods - flexible or programmed? European Journal of Entomology 96:83-102.

. 2004. Seasonal adaptations in Arctic insects. Integrative \& Comparative Biology 44(2):85-94.

Danks, H.V., Downes, J.A., Larson, D.J., and Scudder, G.G.E. 1997. Insects of the Yukon: Characteristics and history. In: Danks, H.V., and Downes, J.A., eds. Insects of the Yukon. Ottawa: Biological Survey of Canada (Terrestrial Arthropods). $963-1013$.

Downes, J.A. 1964. Arctic insects and their environment. The Canadian Entomologist 96(1-2):279-307.

Ferguson, D.C. 1978. The moths of America north of Mexico. Noctuoidea: Lymantriidae. Fascicle 22.2. Faringdon, Oxfordshire: E.W. Classey Limited; Bakersfield, California: The Wedge Entomological Research Foundation. 120 p.

Harris, S.A. 2004. Source areas of North Cordilleran endemic plants: Evidence from Sheep and Outpost Mountains, Kluane National Park, Yukon Territory (Herkunftsgebiete von Endemiten der North Cordillera. Ergebnisse von Sheep und Outpost Mountain, Kluane National Park, Yukon Territory). Erdkunde 58(1):62-81.

Kukal, O. 1995. Winter mortality and the function of larval hibernacula during the 14-year life cycle of an Arctic moth, Gynaephora groenlandica. Canadian Journal of Zoology 73(4):657-662. 
Kukal, O., and Dawson, T.E. 1989. Temperature and food quality influences feeding behavior, assimilation efficiency and growth rate of Arctic woolly-bear caterpillars. Oecologia 79:526-532.

Kukal, O., and Kevan, P.G. 1987. The influence of parasitism on the life history of a High Arctic insect, Gynaephora groenlandica (Wocke) (Lepidoptera: Lymantriidae). Canadian Journal of Zoology 65(1):156-163.

Lafontaine, J.D., and Schmidt, B.C. 2010. Annotated check list of the Noctuoidea (Insecta, Lepidoptera) of North America north of Mexico. ZooKeys 40. 239 p.

Lafontaine, J.D., and Troubridge, J.T. 1999. Two new species of Arctiidae (Lepidoptera) from the Yukon Territory, Canada. Journal of the Entomological Society of British Columbia 96: 89-93.

Lafontaine, J.D., and Wood, D.M. 1997. Butterflies and moths (Lepidoptera) of the Yukon. In: Danks, H.V., and Downes, J.A., eds. Insects of the Yukon. Ottawa: Biological Survey of Canada (Terrestrial Arthropods). 723-785.

Lausi, D., and Nimis, P.L. 1985. Quantitative phytogeography of the Yukon Territory (NW Canada) on a chorologicalphytosociological basis. Vegetatio 59:9-20.

Mølgaard, P., and Morewood, D. 1996. ITEX insect: Gynaephora groenlandica / G. rossii. In: Molau, U., and Mølgaard, P., eds. ITEX manual. Copenhagen: Danish Polar Center. 34-36.

Morewood, W.D. 1998. Reproductive isolation in Arctic species of Gynaephora Hübner (Lepidoptera: Lymantriidae). The Canadian Entomologist 130(4):545-546.
Morewood, W.D., and Lange, P. 1997. Immature stages of High Arctic Gynaephora species (Lymantriidae) and notes on their biology at Alexandra Fiord, Ellesmere Island, Canada. Journal of Research on the Lepidoptera 34:119-141.

Morewood, W.D., and Ring, R.A. 1998. Revision of the life history of the High Arctic moth Gynaephora groenlandica (Wocke) (Lepidoptera: Lymantriidae). Canadian Journal of Zoology 76(7):1371- 1381.

Pohl, G.R., Anweiler, G.G., Schmidt, C., and Kondla, N.G. 2010. An annotated list of the Lepidoptera of Alberta, Canada. ZooKeys 38. 549 p.

Ratnasingham, S., and Hebert, P.D. 2007 BOLD: The barcode of life data system (http://www.barcodinglife.org). Molecular Ecology Notes 7(3):355-364.

Schaefer, P.W., and Castrovillo, P.J. 1979. Gynaephora rossii (Curtis) on Mt. Katahdin, Maine, and Mt. Daisetsu, Japan, and comparisons to records for populations from the Arctic (Lymantriidae). Journal of Research on the Lepidoptera 18(4):241-250.

Witt, T.J., and Ronkay, L., eds. 2011. Lymantriinae and Arctiinae, including phylogeny and check list of the quadrifid Noctuoidea of Europe. Noctuidae Europaeae, Vol. 13. Sorø, Denmark: Entomological Press. 448 p.

Wolff, N.L. 1964. The Lepidoptera of Greenland. Meddelelser om Grønland 159(11). 74 p. 